


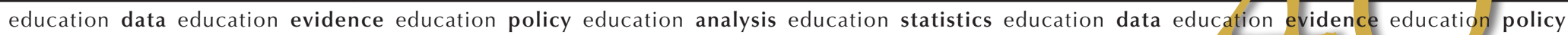

\title{
Does pre-primary education reach those who need it most?
}

- Attendance in pre-primary education is associated with better student performance later on.

- Fifteen-year-old students in 2012 were more likely than 15-year-olds in 2003 to have attended at least one year of pre-primary education.

- The gap in pre-primary attendance rates between socio-economically advantaged and disadvantaged pupils is growing.

As is true for nearly every endeavour, the better prepared one is, the greater the likelihood of success. Education is no exception. Young children who have learned how to behave in groups and have been introduced to the basics of letters and numbers tend to be more open to and ready for the school experience than children who haven't. Pre-primary education serves this purpose well; and if all children, regardless of their socio-economic status, had access to high-quality pre-primary programmes, these programmes could also help to reduce the inequities in readiness for school that are related to pupils' family backgrounds. But results from PISA 2012 find that disadvantaged students are disproportionately missing out on this formative education opportunity.

\section{Enrolment}

in pre-primary education is expanding...
PISA consistently finds that 15 -year-old students who had attended pre-primary education tend to perform better than those who had not attended pre-primary education, even after accounting for the students' socio-economic status. In 2012, in OECD countries that participated in both PISA 2003 and 2012, the difference in PISA mathematics scores between these two groups of students was 51 points - the equivalent of markedly more than a year of formal schooling. 


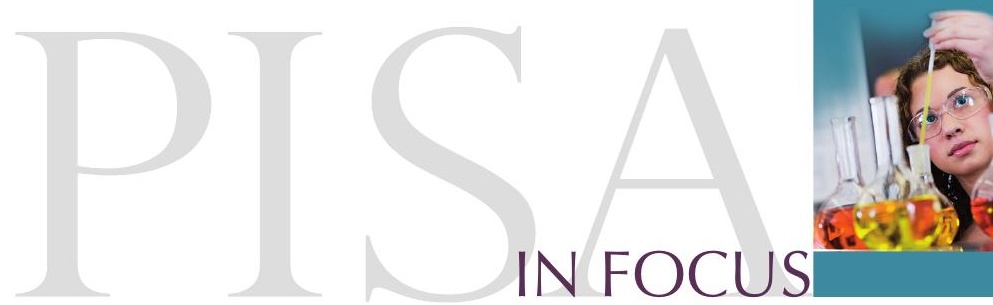

\section{... but not among the pupils who could benefit the most.}

While 15-year-old students in 2012 were more likely than 15-year-olds in 2003 to have attended at least one year of pre-primary education, pre-primary enrolment is higher among advantaged students than disadvantaged students, and higher among students attending advantaged schools than those attending disadvantaged schools. For example, in 2012, an average of $67 \%$ of disadvantaged students had attended pre-primary education for more than one year, while $82 \%$ of advantaged students had done so. This difference in enrolment between advantaged and disadvantaged students is observed in almost all PISA-participating countries and economies. It is largest - 48 percentage points in Poland, and between 25 and 30 percentage points in Portugal, the Slovak Republic and Uruguay. This means that the students who could benefit the most from these programmes - those from disadvantaged backgrounds - are less likely to participate in them. This socio-economic divide widened in the Slovak Republic between 2003 and 2012 as it did, to a lesser extent, in Finland, Greece, Latvia, Luxembourg, Poland and the Russian Federation; it narrowed, however, in Germany, Korea, Macao-China, Portugal and Uruguay.

\section{The socio-economic divide in pre-primary enrolments is widening}

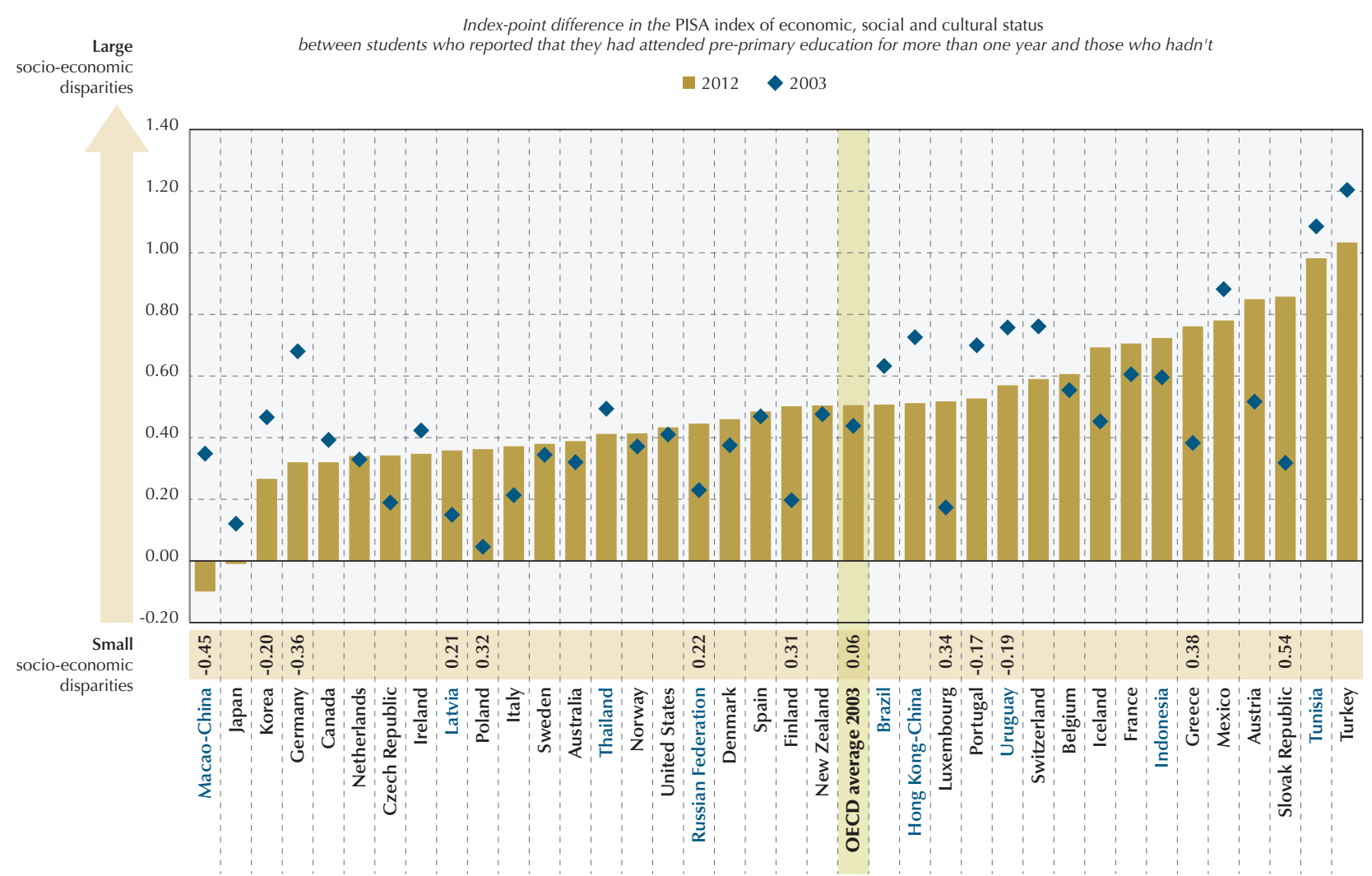

Notes: The change in the index-point difference in the PISA index of economic, social and cultural status between 2003 and 2012 (2012 - 2003$)$ is shown above the country/economy name. Only statistically significant differences are shown.

OECD average 2003 compares only OECD countries with comparable values on the PISA index of economic, social and cultural status since 2003.

Only countries and economies with comparable data from PISA 2003 and PISA 2012 are shown.

Countries and economies are ranked in ascending order of the index-point difference in the PISA index of economic, social and cultural status between students who reported in 2012 that they had attended pre-primary education (ISCED O) for more than one year and those who hadn't.

Source: OECD, PISA 2012 Database, Table IV.1.27.

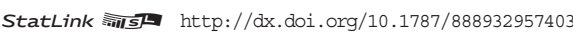


At the same time, the performance gap between students who had attended pre-primary school and those who had not also widened between 2003 and 2012. In 2003, students who had attended pre-primary education scored 40 points higher in mathematics, on average, than students who had not; by 2012, that difference had grown to 51 score points. This difference in mathematics performance grew by more than 25 score points in the Czech Republic, Finland, Greece, Iceland, Italy, Luxembourg, the Slovak Republic, Spain and Thailand. In all of these countries, pre-primary enrolment rates increased significantly during the period; in Finland, Luxembourg and Portugal, they grew by more than five percentage points.
One reason for the increase in

the performance gap lies in the fact that 15-year-old students who had not attended pre-primary education tend to be more socio-economically disadvantaged. Given the overall growth in participation rates, students who reported in 2012 that they had not attended pre-primary education may have come from particularly disadvantaged backgrounds. Taken together, these findings show a strong relationship between attendance in pre-primary school and higher scores in mathematics later on.

The bottom line: PISA results consistently show that a 15-year-old student - regardless of his or her background - who had attended pre-primary school for at least one year performs better in mathematics than a student who hadn't. That pre-primary enrolment rates are growing faster among advantaged students than among disadvantaged students signals that countries have to work harder to ensure that all families, particularly disadvantaged families, have access to high-quality pre-primary education, and to information about such programmes, near where they live. An investment in early education, both for parents and for governments, pays dividends later on in life.

\section{For more information}

Contact Pablo Zoido (Pablo.Zoido@oecd.org)

See OECD (2013), PISA 2012 Results, Excellence through Equity: Giving Every Student the Chance to Succeed

(Volume II), PISA, OECD Publishing, Paris;

OECD (2013), PISA 2012 Results: What Makes Schools Successful? Resources, Policies and Practices (Volume IV), OECD Publishing, Paris.

\section{Visit}

www.pisa.oecd.org

www.oecd.org/pisa/infocus

Education Indicators in Focus

Teaching in Focus

\section{Coming next month \\ Do 15-year-olds know how \\ to manage money?}

Photo credit: ( ) khoa vu/Flickr/Getty Images @ Shutterstock/Kzenon @ Simon Jarratt/Corbis

This paper is published under the responsibility of the Secretary-General of the OECD. The opinions expressed and arguments employed herein do not necessarily reflect the official views of OECD member countries.

This document and any map included herein are without prejudice to the status of or sovereignty over any territory, to the delimitation of international frontiers and boundaries and to the name of any territory, city or area.

The statistical data for Israel are supplied by and under the responsibility of the relevant Israeli authorities. The use of such data by the OECD is without prejudice to the status of the Golan Heights, East Jerusalem and Israeli settlements in the West Bank under the terms of international law. 